\title{
Lumen
}

Selected Proceedings from the Canadian Society for Eighteenth-Century Studies

\section{The Geography of Negotiation: Wales, Anglo-Scottish Sympathy, and Tobias Smollett}

\section{Sharon Alker}

Volume 21, 2002

URI : https://id.erudit.org/iderudit/1012269ar

DOI : https://doi.org/10.7202/1012269ar

Aller au sommaire du numéro

Éditeur(s)

Canadian Society for Eighteenth-Century Studies / Société canadienne d'étude du dix-huitième siècle

ISSN

1209-3696 (imprimé)

1927-8284 (numérique)

Découvrir la revue

Citer cet article

Alker, S. (2002). The Geography of Negotiation: Wales, Anglo-Scottish

Sympathy, and Tobias Smollett. Lumen, 21, 87-103.

https://doi.org/10.7202/1012269ar

Copyright (c) Canadian Society for Eighteenth-Century Studies / Sociéte canadienne d'étude du dix-huitième siècle, 2002
Ce document est protégé par la loi sur le droit d'auteur. L'utilisation des services d'Érudit (y compris la reproduction) est assujettie à sa politique d'utilisation que vous pouvez consulter en ligne.

https://apropos.erudit.org/fr/usagers/politique-dutilisation/ 


\section{The Geography of Negotiation: Wales, Anglo-Scottish Sympathy, and Tobias Smollett}

In their recent reflections on the literary production of the British nation in the eighteenth and nineteenth centuries, Leith Davis and Janet Sorensen adapt Homi Bhabha's notions of ambiguity, slippage and the nation to analyze the way in which British literature negotiates Anglo-Scottish identity. Though both writers are cautious in their application of postcolonial theory to Britain, they recognize its potential, within certain limits, to address the presence of internal hierarchical relationships established through efforts that, at times, 'resemble colonial practices' (Sorensen, 3). This essay takes a similar theoretical approach to the negotiation of Great Britain in Tobias Smollett's Expedition of Humphry Clinker. It hopes to demonstrate that Smollett's use of Wales and Welshness can be illuminated by Bhabha's exploration of ambivalence and the nation. Bhabha argues that 'the mark of the ambivalence of the nation as a narrative strategy - and an apparatus of power - [is] that it produces a continual slippage into analogous, even metonymic, categories, like the people, minorities, or "cultural difference" that continually overlap in the act of writing the nation' (292). Davis inserts authorial agency into this concept of ambivalence, noting that the eighteenth-century authors who imagined Britain were 'conscious that they were in the process of composing their image' (4). The conflict and ambiguity present in various literary conceptions of the imagined nation produced in this period, she suggests, reflect the struggle of the literati to negotiate 'between the incommensurabilities of its [Britain's] internal populations' (5). My argument is that Smollett, in his final novel, uses Wales as a nebulous metonymic category, a British space in which he can accomplish this act of negotiation, particularly as it pertains to Anglo-Scottish relations.

Caroline Mccracken-Flesher, Wolfgang Franke, Davis and other critics have pointed towards the displacement of Anglo-Scottish conflict onto Wales in Humphry Clinker. Franke points out, for example, that while the anglicized Bramble family cannot truly be what Adam Smith would call impartial observers, they are capable of greater sympathy 
towards Scots than the English (101). The idea that Wales and the Welsh represent an imagined locus is also not an original one. In his 1974 article, 'Humphry Clinker and the Two Kingdoms of George III,' Byron Gassman posits that Smollett conceives of Wales as a nostalgic, Augustan, Tory utopia. Yet while the significance of Wales has been noted, the intricacy with which Smollett imagines Wales as a mediating space has not been considered.

Concepts of national identity are always, as Bhabha points out, in medias res (3). Yet, mid-century Wales, as a concept or category rather than as an actual material space, was particularly fluid and open to appropriation for various cultural and national purposes. Cultural representations of Welshness had entered a period of transition in the middle decades of the eighteenth century. In a recent essay, Prys Morgan notes that the years between the middle and end of the century mark 'one of the greatest shifts in the stereotyping of Wild Wales, away from the hostile image of incivility to one of admiration' (274). A number of factors contributed to this rehabilitation, including the interest of English antiquarians in British history and the efforts of the Welsh intelligentsia, centered at the Cymmrodorion Society in London, to ameliorate Welshness.

This revitalization of Welshness was not unprecedented. The Tudor dynasty's claim to Welsh lineage to support its right to the throne had revived and celebrated Welsh antiquity, harnessing it to serve English aspirations. However, English perceptions of Wales had degenerated since the fifteenth century. Peter Lord remarks that between 1640 and 1740 the English imagined the Welsh as a caricatured people who were 'innocents and cowards, as well as thieves [...] smelly and obsessed with eating cheese and recounting their ancestry to the ninth generation' (38). By the middle of the eighteenth century, this perception was transforming once again. Lord notes that at this time '[s]ome fashionable and influential English people were not averse to referring to themselves as Welsh on occasion,' including the prominent David Garrick (61).

The English were not the only national group to appropriate Wales for their own ends during this period. ${ }^{1}$ The Scottish Smollett strategically uses Welsh characters and caricatures to manufacture an acceptable British formation in Humphry Clinker. James Buzard, in an analysis of

1 Wales was not the only component part of Great Britain to be used as a metonymic category in which Britishness could be composed. James Macpherson had appropriated Irish space and heroes in the Ossianic works a decade earlier for similar purposes. 
Walter Scott's Waverley, notes that in Scott's novel the'narrator occupies the translator's mediating position between England and a Gaelicized Scotland' (38). Matthew Bramble and Jery Melford, I will suggest, occupy a similar position in Smollett's narrative, using the temporality and landscape of Wales to mediate between England and Scotland. This mediation is disrupted by a number of the caricatures in the narrative, particularly Lismahago and Tabby (the rather odd emblem of CambroScottish unity), and through the destablizing framework within which Smollett places his narrative. After a discussion of the mediating and disruptive elements of Smollett's Wales, I will consider the way in which the Irish writer, Regina Maria Roche, adapts Smollett's model, in the years preceding the Anglo-Irish Union, to interrogate the concept of Britishness as it applied to Anglo-Irish relations.

Humphry Clinker was not the first novel in which Smollett used a Welsh character to grapple with Anglo-Scottish relations. Despite the numerous problems the Scottish protagonist of Roderick Random encounters in England, the novel ends its representation of Anglo-Scottish relations with metaphoric reconciliation and assimilation. ${ }^{2}$ Smollett explores a Cambro-Scottish alliance, but ultimately rejects it. Morgan, the Welsh first-mate of the man-of-war Thunder, forms a sympathetic association with Roderick after the Scot is press-ganged into service. Together they resist the oppressive forces of the Irish captain, Irish surgeon and a vindictive English midshipman. Smollett's Welsh character is clearly coloured by the traits of the caricatured Welshman, prominent in pamphlets throughout the preceding century. As Morgan enters the narrative his 'fiery eyes' are noted, reflecting the renowned Welsh temperament (Random, 146). His insistence on a pedigree that derives from 'Caractacus king of the Britons' and the 'great lump of Cheshire cheese' he has wrapped in his handkerchief also signify his status as Welsh stereotype (147). In contrast, as Davis notes, the Scottish character Random has the 'ability to erase the signs that betray his difference,' and can ultimately escape national stereotypes (69). Smollett's concept of the Scot's ability to integrate into the British nation is generally optimistic at this point. But while the more rounded Scottish character can ultimately 'pass' as British, Morgan cannot participate in such refashioning, and indeed reappears in Peregrine Pickle with his fiery temper unaltered, having added naïve superstition to his accumulated traits.

2 Roderick Random is considered by Robert Crawford to be the prototype of the national tale (Crawford, 61). 
Wales and Welshness do not operate as a space of mediation in Roderick Random, although the degree of unity that develops between Morgan and Random does foreshadow Humphry Clinker. It is not surprising that Morgan gleefully comments that 'in all likelihood, the ancient Scots and Britons were the same people,' in the moment immediately after Random defeats his English tormentor, Crampley, in a fistfight (156). This national alliance evolves from mutual oppression, and from what Adam Smith would later call, in his Theory of Moral Sentiments, humanity's tendency to enter into abhorrence for whatever gives occasion to the suffering of a fellow creature (or in this case, of a fellow Celt) (70). The men also share certain talents that reflect well on the education system of the British peripheries. The ability of Morgan and Random to read classical Greek demonstrates the superiority of their education to that of their English and Irish shipmates, despite the ridicule they face for their accents and national heritage. ${ }^{3}$

The alliance of marginal characters might infer a degree of Celtic unity against colonization. Yet, Smollett insists there is enough mutual desire for unity between the English centre and the Scottish and Welsh peripheries to shift directly towards allegorical harmony between nations. Both Morgan and Random ultimately marry English women. As Davis notes, this act of assimilation is problematized when Roderick remarks that Narcissa is so delighted with Scotland that 'she has not as yet discovered the last desire of changing her habitation' (69). The narrative ends, not only with a wedding, but also with a lawsuit between Random and Narcissa's brother. Nevertheless, in the union of the young couple there is potential for a complete integration between the two nations. Roderick's final words are that 'my dear angel has been qualmish of late, and begins to grow remarkably round in the waist' (435). The birth of an heir clearly indicates a merging of North and South British identities.

Anglo-Scottish relations in Humphry Clinker are more complex. The odd mixture of classic learning and devotion to cheese that converge in Morgan diverge in Smollett's final novel, where the superior education is allotted to the Anglo-Welsh Matthew and Jery and the characteristics of the caricature colour Tabby and Win. This complexity is not surprising considering the origination of the novel in the years following the vicious dispute between John Wilkes, Smollett and others regarding the effectiveness of the Scottish Lord Bute and the characteristics of his country-

3 As Davis has pointed out, Ireland is the one peripheral nation that does not fare well in Smollett's national negotiations. She notes that 'Smollett himself perpetuates prejudices against the Irish in his narrative' (69). 
men. In this context, it seems, a locus of mediation is essential in order to work 'political sensibilities [...] back into the cultural realm through the resolution of plots,' although this was not the only strategy Smollett employed (Davis, 73). Thomas R. Preston believes that in Humphry Clinker, Smollett creates a dialectic between the English and Scots that can only be resolved through synthesis (200). Eric Rothstein, in 'Scotophilia and Humphry Clinker: The Politics of Beggary, Bugs, and Buttocks,' concludes that $S$ mollett fragments the negative traits typically associated with Scots and distributes them to Scots and non-Scots alike.

Sorensen, working with dialect and language, suggests that Smollett displaces prejudice generally directed at Scots onto 'the uneducated, women, and other speakers of non-standard English' (105). Contemporary critics also inferred that the improvement in Matthew Bramble's temperament as he moves northwards was an attempt to uphold the virtues of Scotland. ${ }^{4}$

Wales, however, is also a central element of Smollett's negotiation of Britain. This use of Wales was not limited to Smollett alone. Occasional references in the public sphere to Welshness as a fictional space of reconcilement in the years between Culloden and Humphry Clinker, suggest that his use of Wales has a history. An anonymous pamphlet entitled The Umpire (1747), written in jest to mediate between the antiScots and anti-English pamphlets that were circulating after Culloden, exemplifies this position. This booklet contains a dialogue between two speakers, one of which tries to position himself as'an ancient Briton' rather than an Englishman because the Welsh are honest and blunt whereas the degenerate, modern English cling to vice and luxury (17). This speaker constructs Wales as a prelapsarian space from which both English and Scottish points of view can be evaluated without bias. Although this position is discounted by his companion, the brief contemplation of Wales in this light implies that ideas connecting Welshness to Anglo-Scottish relations were circulating in the popular press.

Smollett himself had used Welshness to mediate between English and Scottish identity. In The Briton, Smollett responds to a pamphlet attack on Bute, which claimed that there was not a drop of English blood in the Lord Treasurer's whole genealogy, by making reference to Fleance (alleged to be the son of Banquo and the ancestor of the Stuarts).

4 Walter Scott, in his prefatory memoir to Humphry Clinker, notes that Smollett's enemies among the periodical critics 'observed maliciously, but not untruly, that the cynicism of Matthew Bramble becomes gradually softened as he journeys northward [...]' (Scott, Lives 337). 
According to chroniclers of the Scottish Renaissance, Fleance had fled to Wales to escape Macbeth and had married and had children there. Smollett notes that he is not 'sufficiently conversant in antiquity to maintain, that the story of Fleance, the ancestor of the Stuart family is true; but if it is, our minister has in his genealogy a great many drops of Welch blood' (395). Even at this point, Smollett perceives Welshness as an attribute that can connect Celt and Saxon.

Wales itself is conspicuously absent in the novel, with one exception which will be considered later. In general, it exists only in the memory of the correspondents, where it manifests in various ways, according to the character of each of the writers and in the imagined location of the recipients of the letters. Wales must remain off stage - as the place left behind and the future destination - so that Smollett's mediating space is not limited to a specific material place. Only in its absence can Wales be invoked in terms of Bhabha's concept of the nation. An imagined, ambiguous Wales can fulfill both a nostalgic desire for an organic, ordered, non-violent society that exists beyond the misty realms of history and a hope for a potential British utopia where the peripheries and the centre can coexist in peace.

Matthew Bramble's discourse configures Wales in terms of the former. His Wales is an organic community, a place that encapsulates what England was deemed to have been before the corrupting influence of luxury and rapid urbanization. He writes of the noisome crowds and villainous smells at a ball in Bath, noting, '[s]uch is the atmosphere I have exchanged for the pure, elastic, animating air of the Welsh mountains' (66). Writing from London, he contrasts the objects of detestation and disgust that fill the city with the clear air, refreshing sleep, well-furnished table, many amusements, and honest men that exist in Wales $(118,119)$. Bramble places England and Wales in a temporal continuum with virtuous antiquity on one end and luxurious corruption on the other.

Wales not only points towards a virtuous, mythic past, it also subtly points towards a potential imagined future, one which will never be attained within the confines of the text, and indeed not all aim directly towards this utopian locus. But, as will become apparent, it is significant that Lismahago, Tabby and Matthew are ultimately headed towards Wales. Lismahago believes he cannot thrive in either Scotland or England, and originally intends to return to the colonies, where, as Charlotte Sussman notes, Scots can achieve, at least temporarily, a position of authority (603). Smollett suggests that opportunity and success are generally only accessible to the Scot in a distant colony or an imagined space.

If Smollett's Wales can be said to conflate a past golden age and a utopian future, the ambiguity of its borders also facilitates the conflation 
of geography. Wales is more than just an alternate space. There is a degree of elision between Wales and England that facilitates the mediation or translation process. 'Wales' represents an imagined sympathetic, benign England that has been purged of Anglo-Celtic enmity and of the competitive, mocking posture the England of the 1760s had taken towards its northern neighbour. In The Present State of All Nations, written by Smollett between 1760 and 1768, Monmouthshire, the county in which Brambleton Hall is said to exist, is described in the English section of the work rather than the Welsh segment. It is characterized in the following terms. 'This county, which was antiently accounted a part of Wales, in Charles II's reign was taken into the Oxford circuit, and became an English county' (46). In Humphry Clinker, Smollett deliberately places the Bramble family in an ambiguous, hybrid space; one which his contemporaries would know had both Welsh and English affiliations. This impression is further intensified by the Oxford schooling of the two central letter writers, Matthew Bramble and his nephew; an education that clearly leaves them anglicized.

Borders between England and Wales are made ambiguous so that Wales can signify a space in which both English and Scottish attributes intersect, for Wales is also strongly associated with Scotland. We see Wales most clearly through the landscape and inhabitants of Scotland. Matthew and Jery link Wales and Scotland in terms of virtue, landscape, language, the appearance of their inhabitants, and even in terms of an overlapping history. These signifiers of past and present hybridity are woven into both the Highland and Lowland landscape. ${ }^{5}$ Jery, writing of the Highlands, insists, '[t]he peasants of these hills strongly resemble those of Wales in their looks, their manners, and habitations; every thing I see, and hear, and feel, seems Welch - The mountains, vales, and streams; the air and climate; the beef, mutton, and game, are all Welch' (240). Jery makes this claim immediately after making references to the Highlands in which he imagines himself as a Highlander of antiquity.

5 By filling the landscape with these associations, Smollett's central characters are participating in a process not unlike James Buzard's concept of the 'temporalization of space.' Buzard connects this term to both tourism and the historical novel because they 'tell the story of a particular space [...] by filling in its crucial associations. Such associations justify the space $[\ldots]$ by narrating what has made it what it is, worth seeing' (49). Buzard suggests that 'the storied associations of tourism yield closed narratives telling of what transpired in some place in an utterly concluded past' (50). The stories of Matthew and Jery do begin to formulate a cohesive and united British past. But the instability of metonymy itself and the competing stories of various tourists resist tidy closure. 
He speaks of a hunting trip he has made to the 'hills of Morven, where Fingal and his heroes enjoyed the same pastime' (240). Jery tells his friend Watkin Phillips that when he enters the hall of his holiday residence he looks 'for the suspended harp of that divine bard, and listens in hopes of hearing the aerial sound of his respected spirit' (240). Melford is not merely implicitly defending the Ossianic works from contemporary charges of 'fraud,' but is also placing himself in the mode of highland Scot. He hunts and listens for the harp and bardic tales, as he believes the Ossianic heroes once did. He, as a Welshman, is assimilated into the Scottish highlands, and the landscape of the Scottish Highlands becomes Welsh.

Matthew, on the other hand, foregrounds the Lowlands, asserting that the area surrounding Glasgow was clearly a Cumbrian kingdom. He notes,

[t]he great church dedicated to St. Mongah, the river Clyde, and other particulars that smack of our Welch language and customs, contribute to flatter me with the notion, that these people are the descendents of the Britons, who once possessed this country (247).

Smollett uses Bramble to invoke a specific mythic connection between ancient Wales and Scotland. Although William Robertson called the ages before the reign of Kenneth II 'the region of pure fable and conjecture,' some contemporary works asserted that Cambro-Britons had settled in southern Scotland in the distant realms of antiquity (5). James Macpherson, in a footnote to the edition of 'Temora' printed in the 1773 Poems of Ossian, writes of the Maiatæ, 'a name given to the Britons who were settled in the Lowlands, in contradistinction to the Caledonians [...] who were possessed of the more mountainous division of North-Britain' (540). In a later work, he suggests that the Maiatæ were a hybrid people 'who derived their origin, partly from the Cimbri, as well as from the Gael' (History, 85). Thomas Innes, whose Civil and Ecclesiastical History of Scotland was written in the early eighteenth century, though not published in Smollett's lifetime, also supports this connection. He writes that the first known inhabitants of Britain

were the Maiatæ, whom I call Midland Britons, because they dwelt betwixt the southern and northern walls; next to them were the Caledonians, afterwards called Picts [...]. [T] he present inhabitants of Scotland have a right to reckon both these ancient people, the Mæts and the Caledonians, among their predecessors (3). 
In addition to this general Cambro-Scottish association, the church of St. Mungo that Bramble refers to has specific connotations of interaction and mutual assistance between Scotland and Wales. According to Innes, the mother of the sixth-century Scottish St. Kentigern, commonly referred to by the diminutive St. Mungo, is said to have been a Briton. Although Kentigern was believed to have spent much of his life in the area now known as Scotland, the saint also lived for some time in Wales, at one point going there as a place of refuge when the Cambro-British king of Scotland had been stirred up against him. He is said to have founded a monastery in Wales, where he promoted learning among the members, many of whom were scholars. He later returned to southern Scotland where he is said to have evangelized alongside St. Columba. Smollett uses this connection to suggest that Britons and Scots are already intermingled, and that Wales and Scotland have a history of engaging in relationships of mutual exchange. Wales has been a place of refuge for a Cambro-Scottish saint who, in turn, has brought knowledge and learning to Wales. These connections further develop Smollett's form of hybridity. The metonymic category of Wales, in signifying both elements of England and Scotland, gestures towards an integrated British historic and geographic mythology. Scotland, however, is closer to achieving the utopian elements of Wales.

Both men narrate Scotland and its inhabitants without continually measuring them by contemporary English standards. Matthew clearly chides the English for comparing everything they see 'with the same articles in [their] own country,' and Jery emphasizes the importance of his Cambrian knowledge, noting, '[i]f I had never been in Wales, I should have been more struck with the manifest difference in appearance betwixt the peasants and commonalty on different sides of the Tweed' (231, 214). Wales and the Anglo-Welsh are used to generate familiarity and sympathy between the two nations, and, as Preston points out, to project 'the ideal of an emergent but yet unrealized prejudice free Great Britain' (199).

Smollett is aware of resistance to his British ideal, and his novel is not free from anxiety and skepticism about the effectiveness of mediation. In contrast to the relatively strong unifying impulses that mark the closure of Roderick Random, the anxiety inherent in undertaking the process of negotiation in the years immediately following the $1760 \mathrm{~s}$ is most apparent in the absence of Anglo-Scottish unions and the awkwardness of new Cambro-Scots alliances. Matthew's concept of hybridity pragmatically includes contact of a limited sort. He encourages the union of Tabby and Lismahago, and muses, 
we shall find a way to settle them comfortably in our own neighbourhood. I, and my servants, will get rid of a very troublesome and tyrannic gouvernante; and I shall have the benefit of Lismahago's conversation, without being obliged to take more of his company than I desire; for though an olla is a high-flavoured dish, I could not bear to dine upon it every day of my life (273).

The relationship between Matthew - the central personification of a gentler England - and Lismahago is the core of Smollett's revised concept of Britishness. Yet, even here there is a desire for distinctness and limited contact.

The most prominent demonstration of Smollett's reservations about Anglo-Scottish compatibility is the alliance of Tabby and Lismahago, clearly not the ideal way to envision allegorically the embodiment of the British nation. Rather than the unification of the youthful Anglo-Scots couple that appeared in Roderick Random, we are left with the marital merging of an aging Welsh spinster, desperate for a husband of any national heritage, and an eccentric Scottish lieutenant. This strange alliance seems indebted to several sources. It uses elements of Smollett's own brand of the picaresque, and is perhaps comparable to the equally strange union between Mrs. Grizzle and Commodore Trunnion in Peregrine Pickle. From a national point of view, it resembles the satirical works used to negotiate the nation in the years around the Union, such works as John Arbuthnot's image of John Bull and Sister Peg, and the three Scottish brothers and unfaithful English Rosie in Allan Ramsay's 'Three Bonnets.' Working within this tradition may reflect Smollett's desire to rework the union from the beginning.

While Roderick Random ends with the possibility of a birth, Tabby's age (45 according to Jery) makes her ability to produce an heir to the British nation highly questionable. Moreover, as Jery remarks, 'if [the union] produces any fruit, it must be of a very peculiar flavour' (268). This odd juxtapositioning of discordant entities anticipates Walter Scott's Duncan of Knockdunder in The Heart of Midlothian. Duncan, was a man

whose pleasure it was to unite in his own person the dress of the Highlands and Lowlands, wearing on his head a black tie-wig, surmounted by a fierce cockedhat, deeply guarded with gold lace, while the rest of his dress consisted of the plaid and philabeg [...]. The incongruity_had a whimsical and ludicrous effect, as it made his head and body look as if belonging to different individuals [...] (427).

Ian Duncan, in Modern Romance and Transformations of the Novel, contends that Knockdunder 'is a rather tiresome burlesque [...] of the Waverley 
romance ideal of national reconciliation; he parodies that ideal as no organic synthesis, but a botched-together chimera that never lived in history or in nature' (172). Likewise, Lismahago and Tabby foreground the difficulty in merging differences into one harmonious nation, in this case between England and Scotland.

Even more troubling, if we consider this marriage as a form of national union, are questions raised about the couple's commitment to each other. Jery is suspicious of Lismahago's motivations, suggesting that the lieutenant's real devotion is to money and personal security, familiar accusations directed at Scots over the previous decade (267). He also seems to inaccurately attribute these suspicions to his uncle. Smollett weakens this allegation through Matthew's revelation that Lismahago is still entitled to his half pay and 'has amassed eight hundred pounds' in savings, in addition to possessing some relatively valuable (if somewhat strange) goods (344). Scottish intentions, it appears, are possibly honourable. Matthew Bramble, on the other hand, seems to have a more legitimate concern, when he notes that he suspects Tabby of equivocation. He muses, '[s] he attached herself to Lismahago for no other reason but that she despaired of making a more agreeable conquest. - At present, if I am not much mistaken [...] she would gladly convert the widowhood of Baynard to her own advantage' (343).

If Matthew signifies a benign, compassionate England, purged of its acrimony towards Scotland, Tabby is surely marked by residual English resentment. She is greedy where her brother is compassionate, and self-interested in contrast to her brother's commitment to benevolent patriarchy. In many ways, she is his foil, personifying elements of England that have been damaging to Anglo-Scottish relations. Smollett masks this connection by immersing Tabby in a different form of Welshness, one that is closer to Roderick Random's Morgan than it is to the anglicized qualities of Jery, Matthew or Liddy. Tabby, in other words, is ostensibly a Welsh caricature. It may not be a coincidence that her name so closely resembles 'Taffy,' the traditional appellation of the Welsh in the popular literature of the seventeenth and early eighteenth centuries. As Preston notes, both Tabby and Win write in a sort of Welsh dialect, and in addition to carrying the grotesque characteristics of the stereotypical spinster, Tabby possesses numerous traits attributed to the Welsh. Her love of cheese and genealogies $(44,192)$, her susceptibility to strange religious sects (225), and her concern with the minutiae of rural matters (44) all reflect elements derogatorily associated with Welshness throughout the previous century.

Lismahago, as Rothstein has eloquently discussed at length, is also, in part, a caricature, reflecting many of the negative traits circulated in the anti-Scottish ephemera of the sixties. Yet, as Jery remarks at the end 
of the novel, when the lieutenant is treated with respect he is transformed:

His temper, which had been soured and shriveled by disappointment and chagrin, is now swelled out, and smoothed like a raisin in plum-porridge. From being reserved and punctilious, he is become easy and obliging. He cracks jokes, laughs and banters, with the most facetious familiarity; and, in a word, enters into all our schemes of merriment and pastime (347).

Tabby herself is capable of change, when her brother demands it. When she insists Matthew dismiss Humphry for attempting to follow her sarcastic order to kill her dog, Matthew replies that she either dispose of her animal or 'live no longer under the same roof' with him (85). She quickly alters her behaviour. The effect of Matthew's generosity on the Scottish Lismahago, and his ability to restrain his sister when necessary, suggests the match may be achievable, though, like Duncan of Knockdunder, never harmonious.

However, any anxiety inherent in this odd marital union does not necessarily undermine Anglo-Scot relations, for we might argue that Smollett has offered an alternate allegorical form for the Anglo-Scottish relationship. The true alliance, at this historical moment, may be centered in the relationship between Matthew and Lismahago, and be based, not in reproducing a completely assimilated Britain, but in coexisting in civility and equality of discourse; perhaps a more practical model following Smollett's experience with anti-Scots rhetoric.

Smollett is not necessarily suggesting that the union he optimistically predicted at the end of Roderick Random will never be viable again. Rather, he defers this possibility, and instead promotes the idea of Anglo-Welsh alliances. The union of Lydia Melford and George Dennison, and the alliance of Win Jenkins and Humphry Clinker indicate a desire to unite England with the benign, virtuous qualities of Smollett's imagined Wales. The existence of Humphry, the fruit of Matthew Bramble's illicit relationship with Dorothy Twyford of Chippenham, reveals that this union has been attempted before. However, for lack of nurturance and economic support, the virtuous Clinker had been marginalized by English society. In the marriages of these two young, fruitful and legitimately wed couples, Smollett intimates that a second attempt is possible if England lays aside its national prejudices and enters the space of reconciliation. The youth and potential fruitfulness of the couples imply there may be potential for Anglo-Scottish unity, for if their children embrace the qualities of mythical Wales, they may be able to unify with Scots in the future generations. Until that time, Anglo-Scottish relations will be somewhat awkwardly upheld by the odd triad of Matthew, Lismahago and Tabby. 
A further sense of unease is created by two minor characters, who appear only momentarily in Smollett's framing device, but who destabilize national equity in the novel. The only letter that actually comes from Wales is the letter that opens the novel, written by the Reverend Jonathan Dustwich to a London bookseller about the legality of publishing the 'private correspondence of persons still living' (1). In the crucial opening moments of the novel, this letter reveals Smollett's ambivalence about the effectiveness of the mediating project he has undertaken. It simultaneously suggests that Scots can negotiate a respectable position in his imagined Wales and that anti-Scottish prejudice has made its way into this imagined space. Dustwich notes that his attorney has advised him that the letters are likely not actionable and notes,

concerning the personal resentment of Mr. Justice Lismahago, I may say, non flocci facio [I care not a straw] - [...] I am much surprised that more care is not taken to exclude from the commission all such vagrant foreigners as may be justly suspected of disaffection to our happy constitution, in church and state (1).

Lismahago's title suggests he has successfully earned a place in this imagined community. Yet, at the same time, the utopian Wales has been penetrated by prejudice. Once again, the success of North Britons has bred jealousy and an impulse towards exclusion.

The exchange of letters in the framing device also suggests concern that the peripheral nation would be subsumed by England, and more specifically by London. Smollett's mediating space had effectively displaced the negotiation of British identity away from London in order to deconstruct the binary model of Anglo-Scot relations that had emanated from the centre of the nation throughout the sixties. The letters that open this novel reassert the power of the centre over the discourse of negotiation. Through the complicity of a Welsh clergyman, and a London bookseller, who appears to be Anglo-Welsh, the letters that explore reconciliation between the Anglo-Welsh and the Scots have been appropriated and transformed into a commodity.

Smollett's use of Wales and Welshness as a negotiating space, in which Anglo-Scottish desire for unity was tempered by reservations about the feasibility of harmony, was adjusted by writers who followed him. The continuing malleability of Welshness allowed his literary progeny to shape Wales to meet their own particular cultural requirements. In 1772, the year after Humphry Clinker was published, the English playwright Richard Cumberland produced The Fashionable Lover, a popular play in which a virtuous Scotsman, the servant of a debauched member of the English nobility, works alongside a misanthropic English gentleman to restore social order. Along the way, Colin Macleod is 
ridiculed by a French servant, his English master, and most pertinently, his master's Welsh tutor, aptly named Dr. Druid. In the final act, Colin's virtue is clearly revealed to all, with the exception of the eccentric Doctor, who tells Colin, 'be quiet and hear reason; moderate your choler and your passions and your partialities. It is not for a clown like you to prattle and dispute with me' (62). Cumberland uses his Welsh character to infer that anti-Scots rhetoric does not originate with the English. The final speech from the English gentleman denounces such prejudice and promotes charity north of the Tweed, presumably on behalf of English equanimity and generosity. ${ }^{6}$

By 1796, the increasing association of Romanticism with Wales allowed the Irish novelist Regina Maria Roche to develop a different version of Smollett's Wales in her lengthy national tale, Children of the Abbey. Writing thirty years after Smollett, Roche could present Wales as an achievable geographic location that is actually inhabited, at times, by her characters. Ironically, it may have been the development of positive Anglo-Scottish relations in the 1790s that gave Roche a model of cultural integration to work with, one that would have been difficult for Smollett to imagine after his unfortunate dispute with the Wilkites.

Roche's work anticipates the Anglo-Irish union of 1801 through an allegorical alliance of a Scots-Irish heroine with an English hero, but also shares Smollett's anxiety. Her concern is centered on the fear that Irish culture and political freedom will be subsumed by the forces of anglicization. Amanda, the heroine, has difficulty trusting her beau. She is concerned that her poverty makes her an unequal mate, and she is haunted by military images of the Celtic past. Roche tries to resolve this anxiety through the creation of an alternate space, a space in which sympathy between the two lovers and the nations they represent can be developed and nurtured. Like Smollett, she calls this space Wales.

Amanda and Edmund, the lovers, meet at Tudor Hall, one of the Welsh holdings of Edmund's father and a place of intersection between an antique Welsh mythology and an English desire for the cultural richness of such a heritage. This sanitized version of Welsh antiquity is cleansed of the violence that marks Roche's description of Irish and Scottish culture. The icons of warfare, for example, - weapons, armour, and tapestries representing battles - which adorn the Irish and Scottish

6 Cumberland's Dr. Druid is clearly not a metonymic signifier for a heterogeneous nation in the process of constructing itself, but is, rather, a strategy by which he can deflect aggression against Scots away from the English. Nevertheless, I would suggest that the use of Wales in this British context follows in the tradition of Smollett. 
buildings in the novel have been replaced by 'scenes from some of the pastoral poets' (39). In Roche's reading, Wales retains Celtic signifiers, but they have been domesticated. Although the dichotomy between Anglo-Saxon and Celt seems irresolvable at points in the narrative, the characters continually return to this liminal space in which Celt and Anglo-Saxon co-exist harmoniously.

The work of Cumberland and Roche make it clear that the use of Welshness, in various forms, as a malleable locus of national renegotiation did not end with Smollett. As the century drew to a close, however, this mediating space became less necessary for Scotland. Linda Colley reminds us that despite Smollett's anxiety, the decades following the French Revolution brought North and South Britain closer together. In the 1850s, the tumultuous years following the great famine in Ireland, several writers with Irish ancestry, Dinah Craik and Charlotte Brontë, looked for a mediating space in which they could implicitly explore and negotiate British identity. In this particular moment, after the Blue Book scandal and socio-political unrest in Wales, the idea of Welshness had been polluted by history, and could no longer ascend into a transcendent mythological negotiating space. Craik, in her novel Olive, and Brontë, in Villette, elected to use characters from a locus that, in that particular era, had been detached from history, purged of hostility and was associated with benign eccentricity. ${ }^{8}$ They called that space Scotland.

\section{SHARON ALKER \\ University of British Columbia}

7 Directly after a discussion of the unifying influence of Protestant warfare, Colley notes that 'by 1837 , Scotland still retained many of the characteristics of a distinct nation, but it was comfortably contained within a bigger nation. It was British as well as Scottish' (373).

8 Craik and Brontë are working with narratives that engage with British, European and Imperial relations. In this complex context, Scottish characters, and in the case of Craik, Scottish landscape, are used to signify positive aspects of British identity and culture. In Villette, the genial Mr. Home and his gentle daughter Polly are partly Scottish. Invoking the Scottish name of Polly's suitor, Home suggests that John Graham, represented as the epitome of English gentility, is 'descended partly from a Highlander and a chief' (529). Unlike the marginal Lucy Snowe, Home, Polly and Graham appear to be comfortable Britons. In Craik's work, her protagonist, Olive, has an English mother and a Scottish father, and the central male, Harold Gwynne, has a Cambro-Scottish lineage. After their union, the British couple resides in Scotland. 


\section{Works Cited}

Bhabha, Homi K. 'DissemiNation: Time, Narrative, and the Margins of the Modern Nation.' Nation and Narration. Ed. Homi Bhabha. London: Routledge, 1990.

Brontë, Charlotte. Villette. Ed. Mark Lilly. London: Penguin, 1985.

Buzard, James. 'Translation and Tourism: Scott's Waverley and the Rendering of Culture.' The Yale Journal of Criticism 8:2 (1995): 31-59.

Colley, Linda. Britons: Forging the Nation 1707-1837. London: Pimlico, 1994.

Crawford, Robert. Devolving English Literature. Oxford: Clarendon, 1992.

Cumberland, Richard. The Fashionable Lover. London, 1772.

Davis, Leith. Acts of Union: Scotland and the Literary Negotiation of the British Nation 17071830. Stanford: Stanford UP, 1998.

Duncan, Ian. Modern Romance and Transformations of the Novel: the Gothic, Scott, Dickens. New York: Cambridge UP, 1992.

Franke, Wolfgang. 'Smollett's Humphry Clinker as a "Party Novel."' Studies in Scottish Literature ix: 2-3 (Oct-Jan, 1971-2): 97-106.

Gassman, Byron, O.M. Brack Jr., eds. Poems, Plays and The Briton: Tobias Smollett. Athens: University of Georgia Press, 1993.

Innes, Thomas. The Civil and Ecclesiastical History of Scotland. Aberdeen, 1853.

Lord, Peter. Words with Pictures: Welsh Images and Images of Wales in the Popular Press, 1640-1860. Aberystwyth: Planet, 1995.

Macpherson, James. 'The Works of Ossian the Son of Fingal.' Vol. 2. The Poems of Ossian and Related Works. Ed. Howard Gaskill. Edinburgh: Edinburgh UP, 1996. . An Introduction to the History of Great Britain and Ireland. $3^{\text {rd }}$ ed. London, 1773.

Mccracken-Flesher, Caroline. 'English Hegemony/Scottish Subjectivity: Calvinism and Cultural Resistance in the Nineteenth-Century "North British" Novel.' Diss. Brown University, 1989.

Morgan, Prys. 'Wild Wales: Civilizing the Welsh from the Sixteenth to the Nineteenth Centuries.' Civil Histories: Essays Presented to Sir Keith Thomas. Ed. Peter Burke, Brian Harrison, and Paul Slack. Oxford: Oxford UP, 2000. 265-283.

Preston, Thomas, R. 'Contrary Scriptings: Implied National Narratives in Burns and Smollett.' Love and Liberty: Robert Burns: A Bicentenary Celebration. Ed. Kenneth Simpson. East Linton: Tuckwell Press, 1997. 198-216.

Robertson, William. The History of Scotland during the Reigns of Queen Mary, and of King James VI. Till his Accession to the Crown of England [...]. Vol. 1. London, 1771.

Roche, Regina Maria. Children of the Abbey. Chicago: Rand, McNally \& Co., n.d.

Rothstein, Eric. 'Scotophilia and Humphry Clinker: The Politics of Beggary, Bugs, and Buttocks.' University of Toronto Quarterly 52:1 (1982): 63-78.

Scott, Walter. The Heart of Midlothian. Oxford: Oxford UP, 1982. 
. Lives of the Novelists. Vol.1. Tobias Smollett: The Critical Heritage. Ed. Lionel Kelly. London: Routledge, 1987. 350-364.

Smith, Adam. The Theory of Moral Sentiments. Indianapolis: Liberty Fund, 1984.

Smollett, Tobias. The Adventures of Roderick Random. Ed. Paul-Gabriel Boucé. Oxford: Oxford UP, 1979.

The Briton. Ed. Byron Gassman. Poems, Plays and The Briton. Georgia: University of Georgia Press, 1993.

. The Expedition of Humphry Clinker. Ed. Lewis M. Knapp. Revised Paul-Gabriel Boucé. Oxford: Oxford UP, 1984.

. The Present State of All Nations; Containing a Geographical, Natural, Commercial, and Political History of all the Countries in the Known World. Vol. 3. London: 1768-89.

Sorensen, Janet. The Grammar of Empire in Eighteenth-Century British Writing. Cambridge: Cambridge UP, 2000.

Sussman, Charlotte. 'Lismahago's Captivity: Transculturation in Humphry Clinker.' ELH 61 (1994): 597-618.

The Umpire: Being a Serio-Comical Dissection of Three Learned and Important Dissertations on the Nature of Englishmen and Scots. London, 1747. 